\title{
Chapter 2: Women and Politics
}

\author{
"Let the woman learn in silence with all \\ subjection. But I suffer not a woman to \\ teach, nor to usurp authority over the \\ man, but to be in silence." - \\ 1 Timothy 2:11-14
}

\subsection{Julian's Universal Salvation}

The first chapter has shown that the female visionaries used the negative stereotypes around their bodies in order to gain authority through their voices and their writings. In this chapter, the focus lies on politics. At the time in which they lived, women were said to be too weak and frail to speak in public, let alone to be involved in politics. Yet, as these women visionaries will show, they and their writings were very political, albeit to different degrees and for different reasons. Commenting on the political nature of these writers, Diane Watt states:

Unlike many of their continental counterparts Margery Kempe and almost all other late medieval women prophets and visionaries in England only intervened in matters relating to the communities in which they lived [...] Margery Kempe [...] was very much a local prophet, concerned only with questions involving her immediate communities. [...] English women's prophecy became more politicized with the Reformation. (55)

Despite this claim that medieval English visionaries were less political than visionary writers elsewhere in Europe, and even less political than their seventeenth century counterparts, I would nonetheless argue that Margery and Julian were clearly political. Firstly, religion is often not separable from politics, neither in the Middle Ages nor in the seventeenth century. Secondly, 
writing and public speaking can already be seen as political acts in themselves for these female visionary writers.

As already mentioned in the first chapter, Julian states in her first revelation that she writes for everybody: "I say nott thy to them that be wyse, for they wytt it wele. But I sey it to you that be symple, for ease and comfort, for we be alle one in love" (Showings 16). Indeed, the revelations are shown to her by God "in comfort of us alle" (Showings 15). This simple statement has various implications. First of all, Julian tells the reader that she does not write for the learned because they already know the content of her revelations. With this comment, she is able to legitimise her writings, making it clear that everything she writes is already well known by the learned. More importantly, however, she says that she writes for the simple, the unlearned, for her "evyn Cristen," in short, for everybody. As such, the revelations are an unmediated message from God through Julian to the people. Mediation is, of course, an important concept in the Church's teachings, as God's words are delivered through the Church and are not typically a private and direct conversation between God and his people. ${ }^{1}$ The Showings, however, contradict the Church's teachings by the mere fact that Julian, rather than a priest, is the intermediary. That she is aware of the fact that her revelations are potentially dangerous in this regard can be seen in the way she affirms everything the Church teaches in her first revelation: "But in all thing I beleve as holy chyrch prechyth and techyth. For the feyth of holy chyrch, which I had before hand understondyng and as I hope by the grace of God wylle fully kepe it in use and in custome, stode contynually in my syghte, wyllyng and meanyng never to receyve ony thyng that myght be contrary ther to" (Showings 16).

Julian states clearly that she believes in the Church's teachings and that she does not want to write anything that runs counter to these, her revelations are decidedly subversive in parts nonetheless. In revelations xiii and xiv, for instance, she struggles with the Church's teaching that God is full of wrath and that sinners are damned. This is because God shows her in her revelations that "Alle maner thyng shall be welle" (Showings 44). Julian, thus, cannot reconcile her own understanding, for example that she should have faith in God's word and believe Him when He says that everything shall be well, with the Church's teaching that heathens and sinners are damned (Showings 45). After all, God

1 Prayers are, needless to say, a private conversation between Cod and his people. What is meant here is the word of God and His teachings, which are mediated through the Church. 
does not show her hell or sin, but only His goodness and love for everyone. For several pages, she contrasts what the "holy chyrch techyth [her] to beleve," namely that "we oughte to leve, and leve many good dedys undone that we oughte to do, therfore we deserve payne, blame, and wrath," with what she saw in her revelation: "And nott withstanding alle this, I saw verely that oure Lorde was nevyr wroth nor nevyr shall. For he is God, he is good, he is truth, he is love, he is pees" (Showings 64). Similarly, in revelations xiii and xiv, Julian goes back and forth, making her struggle visible by repeating sentences as well as trying different approaches to the topic. In revelation xiv, for instance, she asks God: "Yf I take it thus, that we be no synners nor no blame wurthy, it semyth as I shulde erre and faile of knwoyng of this soth. And yf it be tru that we be synners and blame wurthy, good Lorde, how may it than be that I can nott see this truth in the, whych arte my God, my maker in whom I desyer to se alle truth?" (Showings 69).

This question and Julian's struggle between the Church's teachings and her revelations mark the beginning of her theodicy of universal salvation - a theodicy that is in stark contrast with what she has thus far been taught by the Church. In answer to her question to God, which is stated above, Julian is given another revelation about God and the servant. In chapter 51, she sees a servant who is willing to do his lord's bidding, but falls into a pit, no longer able to serve or see his master's face. The servant still expresses a desire to serve and, similarly, the lord's love for the servant never falters. Julian goes on to explain that the servant is Adam and his fall into the pit represents the first sin. At the same time, she makes it clear that the servant is not only Adam, but also Christ, as "Goddys Sonne myght nott be seperath from Adam, for by Adam I understond alle man" (Showings 76). Christ, thus, in becoming a man in order to redeem mankind, becomes the servant, who represents all mankind who participated in the original sin. Through his sacrifice, Christ descends into hell and redeems Adam and thus everyone else along with him. This is the answer to Julian's question; we are all saved through Christ as "oure good Lorde Jhesu [has] taken uppon hym all oure blame, and therfore oure Fader may nor wyll no more blame assigne to us than to hys owne derwurthy Son Jhesu Cryst" (Showings 76).

The notion of felix culpa, or the fortunate fall, is, of course, nothing new. Nor is the concept of Christ being made flesh and redeeming us from original sin. However, Julian's theodicy does not stop there. Her revelation shows her that Adam is Christ and that Christ is Adam. In the light of this, mankind is not only absolved from original sin, but cannot be blamed for future sin. 
This is because everybody has two parts in themselves: "the goodnesse that we have is of Jesu Crist, the febilnesse and blyndnesse that we have is of Adam" (Showings 76). Here, Julian also begins to include her notion of the imago dei, as described in chapter 1 . The part in our soul that she calls "substance," which is always a part of God, is in this revelation connected to the part of us which was and is Christ. Thus, by exchanging Adam with Christ, she understands that through God's grace, there is no sin and no blame and, thus, no more hell.

I sawe and understode in oure Lordy a menyng that we may nott in this lyfe kepe us fro synne, alle holy in full clenesse as we shall be in hevyn. But we may wele by grace kepe us fro the synnes whych wolde lede us to endlesse payne, as holy chyrch techyth us, [...] wyttyng that we may nott stonde a twynglyng of an ey but with kepyng of grace, and reverently cleve to God, in him only trustyng. (Showings 81)

For Julian, it is clear that we are not able to refrain from sin, but that, through God's grace and the part of the soul that is Christ, everyone, without exception, will ultimately be saved.

Interestingly, Julian never mentions Eve in this revelation. Instead, she talks about Adam's fall and his feebleness and weakness. Thus, despite the fact that Eve is often connected to the fall and original sin and is called the first transgressor, in Julian's version, it is Adam who falls into the pit, causing the fortunate fall from which Christ has to save us. After the fall it is thus Adam and not Eve who has to "do the grettest labour and the hardest traveyle that is" (Showings 75). Furthermore, Julian not only leaves Eve out of the first transgression, but she clearly vindicates the flesh and thus the body in her revelation about God and the servant: "And oure foule, dedely flessch that Goddys Son toke uppon hym, whych was Adam's olde kyrtyll, streyte, bare, and shorte, then by oure Savyoure was made feyer, new, whyt, and bryght, and of endlesse clennesse" (Showings 78). Adam's old kirtle, and thus his flesh, is made new through Christ, making it bright and clean. Just as in the discussion in chapter 1 , the flesh is part of Christ, giving Julian the starting point for her discussion about the bipartite soul, in which both substance and sensuality are positively connoted. Even though Julian tries to repeatedly make it clear that she believes in the Church's teachings, her parable of God and the servant and her universal salvation theory make it difficult not to see her theodicy as subversive and political. 


\subsection{Language and Heresy}

Language is another important area in which Julian is part of the political discussion of the time. Of course, discussions about language and the word of God have a long tradition. In 2 Corinthians 12: 2-4, for instance, we read:

I knew a man in Christ above fourteen years ago, (whether in the body, I cannot tell; or whether out of the body, I cannot tell: God knoweth;) such an one caught up to the third heaven. And I knew such a man, (whether in the body, or out of the body, I cannot tell: God knoweth;) How that he was caught up into paradise, and heard unspeakable words, which it is not lawful for a man to utter.

This passage illustrates the crucial point of the discussion: how is it possible to utter something that is unspeakable? God is transcendent and it is not possible for human beings to understand God's words fully. Human language is also fallible so the question remains: is what we are reading in the Bible God's word or is it mediated through fallible human language? Augustine, for instance, while describing an out of body experience, explains the problem in the following way:

Wisdom is not made, but is as she has been and forever shall be; for 'to have been' and 'to be hereafter' do not apply to her, but only 'to be,' because she is eternal and 'to have been' and 'to be hereafter' are not eternal. And while we were thus speaking and straining after her, we just barely touched her with the whole effort of our hearts. [...] We returned to the sounds of our own tongue, where the spoken word had both beginning and end. (Chapter $\mathrm{X}$, Book 9)

Here, the argument is that wisdom, and God for that matter, is eternal. $\mathrm{Hu}$ man language, in contrast, cannot exist in eternity as it has a beginning and an end. On earth, as human beings, we exist through time, past, present and future, with everything clearly demarcated by a beginning and an end. In this sense, there is no possibility to understand or talk about the word of God. Human language will thus always be a vehicle that fails to express the eternal wisdom of God.

This discussion about fallible human language led to a tradition known as the via negativa. The concept goes back to Pseudo-Dionysius the Areopagite (around $\mathrm{AD}$ 500), who maintains that we can achieve a union with God but only through 'unknowing' everything, leaving all earthliness behind and being 
in a state of complete darkness. For Pseudo-Dionysius, divine grace makes it possible to attain a union with God in contemplation. However, in this contemplation, you must "forsake your bodily sense [...], and also your spiritual senses, otherwise known as your intellectual activities; [...] and all things that now exist or that have existed though they do not now exist; and all things that do not now exist, or that may exist in the future though they do not now exist" (2). Here, Pseudo-Dionysius voices similar sentiments as Augustine did. In order to attain a spiritual union with God, one has to achieve some sense of eternity, leaving behind the past, present and future. He further states: "once everything has been negated in this way, you will be drawn up in your feelings above understanding to the radiance of divine darkness that transcends all being" (2). This darkness represents the 'unknowing' of everything, which is accomplished by means of negation, hence the name of the tradition. In the end, "once this ascent is over, there will be no voice, and all will be united with that which is unspeakable" (2). As such, language must be left behind as there is no voice in a union with God. We become one with the unspeakable itself.

In the last quarter of the fourteenth century, the unknown author of The Cloud of Unknowing presents similar ideas. In chapter 70, he states that he only wishes to cite St. Denis (whom he confuses for Pseudo-Dionysius) as the authority of his work. He encapsulates his own work as well as that of Pseudo-Dionysius in the following quote: "The godliest knowledge of God is that which is known through ignorance" (96). Negation and a spiritual darkness that becomes a cloud in his work are, thus, necessary in a union with God through contemplation. As was the case with Rolle's and Hilton's views, this kind of ecstasy is only rarely achieved by human beings and the unknown author makes it clear from the start that his book is not for everyone. Indeed, he goes out of his way to restrict his readership to the perfect Christian:

I command and beseech you [...] whoever you my be that have this book in your possession [...] that so far as you are able you do not willingly and deliberately read it, copy it, speak of it, or allow it to be read [...] by anyone or to anyone, except by or to a person, who, in your opinion, has undertaken truly and without reservation to be a perfect follower of Christ [...] and one too who does all he can, and, in your opinion, has long done so, to prepare himself for the contemplative life by means of virtuous active living; for otherwise it has nothing to do with him. (11) 
As we have seen in the first chapter, this is very similar to the approach taken by Rolle and Hilton but it stands in stark contrast to that of Julian and Margery. Julian's work is explicitly for everyone. It is written in the vernacular, from one 'unlearned' person to another, and is, as she says, for "evyn Cristen." The same holds true for Margery, who is instructed by God to write about her way of life for the entire world to know. Language is of crucial importance here. The author of the Cloud describes it as a "clumsy, beastlike tongue" (118) and speech as a "bodily activity" (88). Nonetheless, only the vernacular makes it possible at all for these spiritual works to be widely read and understood by everyone. Thus, not only is language itself seen as inadequate in understanding the word of God, the discussion also shifts to the vernacular.

The use of the vernacular in religious texts at the end of the fourteenth and the beginning of the fifteenth century is clearly political. This can be first and foremost seen by the Constitutions of Thomas Arundel, Archbishop of Canterbury, drafted in 1407 and published in 1409. In fact, Nicholas Watson rightly states that "Arundel's Constitutions [...] need to be regarded as the linchpin of a broader attempt to limit religious discussion and writing in the vernacular" "Censorship" 824) and that "all but the most pragmatic religious writing could come to be seen, by the early fifteenth century, as dangerous" ("Censorship" 825). Even though it is quite evident that Arundel's Constitutions are aimed against the Lollards, they have further ramifications that are directed towards English religious writings in general. In his first constitution, Arundel states:

That no maner of person seculer or reguler, being authorised to preach by the lawes now prescribed, or licenced by special priviledge: shal take upon him the office of preaching the word of Cod, or by any meanes preach unto the clergy or Laitie, either within the Churche or without, in English, except he first present himselfe, and be examined of the Ordinary of the place where he preacheth. (Foxe, 1583 edition, Book 5, p. 548 (524))

In this first constitution, the English language as such becomes the problematic issue. In connection with constitution seven, one could argue that Arundel's concern is the vernacular language, which cannot convey religious concepts or the word of God, as was the case in the general discussion about human language in the passages above. It also reflects a general concern about translating texts. He states that "it is a dangerous thinge [...] to translate the text of the holy scripture out of one tongue into an other: for in the translation the same sense is not alwayes kept [...] We therefore decree and ordayne, 
that no man [...] translate any text of the Scripture into English [...] by way of a booke, libell, or treatise" (Foxe, 1583 edition, Book 5, p. 549 (525)). However, if one looks at constitution five in which he decrees:

no scholemaisters and teachers what soever, that instruct children in grammer, or [...] in primitive sciences... intermingle any thing concerning the catholicke fayth, contrary to the determinations of the church. Nor shall suffer theyr schollers to expound the holy Scripures, [...] not shal permit them to dispute openly or privily concerning the catholicke fayth (Foxe, 1583 edition, Book 5, p. 549 (525)),

then it becomes clear that there is more behind the decrees than only what might be lost in translation.

Arundel's Constitutions are the culmination of the Oxford translation debate ${ }^{2}$ in which scholars on both sides argued about the role of the vernacular in religious writings. The Wycliffite Bible and general English religious writings were at the core of this argument. Discussions about translations of the Bible were the primary concern. After all, during copying and translating, errors can arise and there are always certain things that cannot be translated into another language due to the fact that the terminology does not exist in the target language. The question of the fallibility of human language becomes even more problematic when the word of God is copied and translated over and over again. However, as seen in the constitutions, the debate was not only about translation. Prohibiting preaching in English as well as forbidding all discussion about the teachings of the Church in schoolrooms and in private make it clear that the discussion was also about Church politics. There was clearly a fear that if everyone were able to read the Bible and talk to each other about scripture, everyone could become a teacher and the clergy would become irrelevant. Using English in religious texts, as Julian and Margery do, in order to reach a wider audience, and one that was not necessarily educated, was therefore dangerous in its own right.

This can also be seen in Nicholas Love's The Mirror of the Blessed Life of Jesus Christ. Love uses the momentum of Arundel's Constitutions to publish his work. Indeed, Michael G. Sargent argues that Love's Mirror "was the most important literary version of the life of Christ in English before modern times. In fact, to judge by the number of surviving manuscripts and early prints, it was one well as Nicholas Watson "Censorship" 842-43. 
of the most well-read books in late-medieval England" (Love, "Introduction" ix). Although the Mirror is written in English, it becomes clear that it fits right into Arundel's politics, as testified by a Memorandum at the beginning of the book. Love states that the Mirror

was presented in London by its compiler, N, to the Most Reverend Father and Lord in Christ, Lord Thomas Arundel, Archbishop of Canterbury, for inspection and due examination before it was freely communicated. Who after examining it for several days, returning it to the above-mentioned author, commended and approved it personally, and further decreed and commanded by his metropolitan authority that it rather be published universally for the edification of the faithful and the confutation of heretics or lollards. (xv)

In this Memorandum, Love makes it clear that he has Arundel's complete approval and his express permission for the book to be "published universally." In contrast to other religious texts that are written in English, this book is, therefore, set up as a text that is for the edification of all that are faithful, making it a book that is going to prove the heretics and Lollards wrong.

The fact that this book clearly takes aim at the unfaithful is evident in the margins of several passages, in which Love writes "contra lollardos" signal his arguments confuting the Lollards. He states that contrary to "the fals opinyon of lollardes" (90), confession needs to be said out loud to a priest "that [God] hath specialy ordeynet in his stede" (91). He also devotes several paragraphs to talking about transubstantiation in the Eucharist (151-154), calling the Lollards "lewede" and "fals" (152) and stating that: "I sal say more over sumwhat in speciale that I knowe sotherly of the gracious wirching in sensible felyng of this blessed sacrament, the which merveylouse wirching \& felyng above comune kynde of manne sheweth \& proveth sovereynly, the blessed bodily presence of Jesu in that sacrament" (152). Love's comments here are motivated by the Lollards' attacks on transubstantiation and on the pronunciation of absolution, which are their attempt to undermine clerical power, 
the very power that Love seeks to protect. ${ }^{4}$ Fundamentally, if God alone is able to pronounce absolution and if the miracle of transubstantiation by a priest is placed in doubt, the clergy becomes irrelevant. Thus, though Love's text is written in English, the clear attacks on the Lollards and the presence of the Memorandum at the beginning undoubtedly further Arundel's cause and aid the unhindered dissemination of Love's book.

Love's awareness of the political landscape is evident from the proem. He states that several books have been written by "devoute men not onelich to clerkes in latyne, but also in Englyshe to lewde men \& women \& hem that bene of symple undirstondyng" (10). These "symple creatures the whiche as childryn haven nede to be fedde with mylke of lyghte doctryne \& not with sadde mete of grete clargye" (10). Here, Love contrasts the false texts written by the Lollards in English with other texts that were written in English first and foremost for the "symple creatures" who are incapable of understanding difficult texts. English is here used as a means by which to bring lighter doctrine to the masses, setting these books apart from the sophisticated Latin texts by the clergy. In addition, Love comments on several authors, such as Hilton, Rolle, Julian and others, who contemplate Christ as a man:

[T] he monhede of cryste is more likyng more spedefull \& more sykere than is hyghe contemplacion of the godhed ande therfore to hem is pryncipally to be wette in mynde the ymage of crystes Incarnacion passion \& Resurreccion so that a symple soule that kan not thenke bot bodyes or bodily thinges mowe have somwhat accordynge unto is affecion where with he maye fede \& stire his devocion. (10)

By equating the contemplation of Christ as a man to simple souls who are not able to reach higher contemplation, Love diminishes authors who use affective piety in order to connect with Christ or God. The body and "bodily thinges" more generally are here again used to indicate those with a lower mental capacity and the uneducated. Love's book thus stands both against the teachings of the Lollards as well as authors who use affective piety in order

See the "Twelve Conclusions of the Lollards," in which the fourth conclusion states that the Eucharist is a "feynid miracle" and that "every trewe man and womman in Codis lawe make the sacrament of the bred withoutin oni sich miracle" (Hudson, English Wycliffite Writings 25). The ninth conclusion, furthermore, maintains that priests do not have the power to pronounce absolution and that it only "enhaunsith prestis pride" (Hudson, English Wycliffite Writings 27). 
to reach a higher contemplative level. It also demonstrates the contemporary fear of the dangers of the English language and the interest of the masses in religious matters, as the above passages illustrate. Julian and Margery both participate in this political landscape and have to negotiate the difficulty to legitimise their texts written in English.

\subsection{Margery and Heresy}

Margery's participation in the political landscape of her time is not limited to her use of the vernacular, it is also reflected in her views and behaviour, which can be termed heretical. Lynn Staley, for example states that "[Kempe $]^{5}$ uses Margery in a way that evinces her sensitivity to the whole range of issues that had accrued around the Lollard heresy and that suggests her sympathies for what might loosely be called Lollard views" (127). As was discussed, such Lollard views as instigated by John Wyclif included reading the (vernacular) Bible as the sole authority and the limitation of priesthood by denying the clergy the power to give absolution and by disputing the miracle of transubstantiation in the Eucharist. Lollards also condemned any form of idolatry, including images and pilgrimages, and swearing. ${ }^{6}$ Given their belief that the Bible was the sole authority and that every good man could be a priest, the threat that the Lollards posed to the Catholic Church was great and had inevitable consequences. Indeed, Margery is accused of being a Lollard several times in her text. One of the issues that comes up again and again is Margery's mobility and her talking, if not preaching, about God to numerous people on her journeys.

From Paul's teaching, it is clear that women should neither teach nor preach: "Let the woman learn in silence with all subjection. But I suffer not a woman to teach, nor to usurp authority over the man, but to be in silence. For Adam was first formed, then Eve. And Adam was not deceived, but the woman being deceived was in transgression" (1 Tim. 2:11-14). Adam's superiority is established thereby as being "first formed" and as we have already seen, it is Eve is who is responsible for the original sin. As a consequence, women are

Lynn Staley makes a distinction between Margery as a subject and Kempe as the author of the Book (3).

6 See, for instance, the "Twelve Conclusions of the Lollards" (24-29) in Hudson Selections from English Wycliffite Writings. 
not permitted to teach, and even learning should be done in silence and only in subjugation to men. ${ }^{7}$ Women are allowed to talk at home to other women or to their children but as the inferior sex they are unable to teach or preach outside the domestic space, especially not to men, who are the superior sex. The arguments as to why women are not allowed to preach are summarised by Walter Brut, a Lollard, whose trial took place in 1391, as follows:

(i) A woman, because of her female sex, is by nature subject to man, or if not by nature, at least by command of the Lord. Therefore, it is not her place to teach in public [...]. (ii) So that men will not be led into sexual desire by the public teaching of a woman, it is forbidden to them to teach in public because in so doing they would harm men rather than benefit them. (iii) The third reason is that women in general have weak and unstable natures and thus they are incomplete in wisdome; therefore, they are not allowed to teach in public [...]. (Blamires 252-53)

The first and the third point are also outlined by St. Paul, quoted above, and point to the inferiority of women in their mind as well as their bodies. Interestingly, Brut elaborates on the second point, claiming that "although the beauty of her appearance and every movement of woman may lead men to sexual desire, it is chiefly the sweetness of her voice and the pleasure of hearing her words that does this" (Blamires 252). The suggestion is that men are distracted and led astray even by hearing a woman's voice and, thus, the content of what she is saying does not seem to matter.

When Margery Kempe is interrogated in the articles of faith, it becomes clear that her voice has the power to lead people astray. At a particular moment, a mayor says to Margery: "I wil wetyn why thow gost in white clothys, for I trowe thow art comyn hedyr to han awey owr wyvys fro us and ledyn hem wyth the" (236). On another occasion when she is examined by the Archbishop of York, the clerics maintain: "We knowyn wel that sche can the articles of the feith, but we wil not suffyr hir to dwellyn among us, for the pepil hath gret feyth in hir dalyawnce, and peraventur sche myth pervertyn summe of hem" (250). Margery's interrogators are forced to acknowledge that "sche knowith

See also 1 Cor. 34-35 for women preaching and learning: "Let your women keep silence in the churches: for it is not permitted unto them to speak; but they are commanded to be under obedience, as also saith the law. And if they will learn any thing, let them ask their husbands at home: for it is a shame for women to speak in the church." 
hir feyth" (250) yet the seductiveness of her voice still seems to be a problem, as she is able to lure away wives and to lead people astray.

As such, the main problem is that Margery is not allowed to teach, regardless of the content. This becomes clear shortly after the passage quoted above: "Than seyd the Erchebischop to hir: "Thow schalt sweryn that thu [ne] schalt techyn ne chalengyn the pepil in my diocyse"' (251). However, she refuses to swear and maintains that God does not forbid speaking of Him. She even sets out to prove it with evidence from the Gospel:

And also the Cospel makyth mencyon that, whan the woman had herd owr Lord prechyd, sche cam beforn hym wyth a lowde voys and seyd: 'Blyssed be the wombe that the bar and the tety that yaf the sowkyn.' Than owr Lord seyd ayen to hir: 'Forsothe, so ar thei blissed that heryn the word of Cod and kepyn it.' And therfor, sir, me thynkyth that the Gospel yevyth me leve to spekyn of Cod. (251-252)

Margery here demonstrates that she knows scripture and that she is able to quote from it in English. This is exactly what Arundel's Constitutions aimed to prohibit, as the embracing of the vernacular meant that everyone would be able to read the Bible and to discuss matters that were formerly the preserve of the clergy. Clearly, Margery's citation of the Gospel makes her seem even more suspicious. One particular cleric quickly comments that she must have a devil in her, before quoting from St. Paul's instruction "that no woman schulde prechyn" (253). However, as Margery is evidently aware of the ramifications of being branded a Lollard, she gives a very clever answer: "I preche not, ser; I come in no pulpytt. I use but comownycacyon and good wordys, and that wil I do whil I leve" (253). Although she maintains that she is not preaching, but rather only using good words in her conversations with other people, she comes very close to comparing herself to a preacher shortly afterwards:

in place wher my dwellyng is most, is a worthy clerk, a good prechar, whech boldl spekyth ageyn the mysgovernawns of the pepil and wil glatyr no man. Heyth many tymes in the pulpit, "Yyf any man be evyl plesyd wyth my prechyng, note hym wel, for he is gylty." And ryth so, ser,' seyd sche to the clerk, 'far ye be me, God foryeve it yow.' (256)

Here, the suggestion is that the clerk is guilty for not being pleased with Margery's tale about the priest and is in need of forgiveness. In this analogy, it is Margery who boldly speaks out against people and their faults. Though she does not do so from the pulpit, this conforms to preaching in terms of 
content. Nonetheless, it is difficult to find fault with what Margery says, as she knows to give the clerics and the Archbishop the right answers to the articles of faith. Thus, she manages to legitimise her unorthodox behaviour of publicly speaking (or preaching?) about God, even though she is accused of being a Lollard several times.

Margery's strategy does not end with the clerks, as she is also quite cunning in legitimising her public speeches for the reader. Shortly after her encounter with the Archbishop of York, we read the following: "Than stode sche lokyng owt at a wyndown, tellyng many good talys to hem that wolde heryn hir, in-so-meche that women wept sor and seyde wyth gret hevynes of her hertys: 'Alas, woman, why schalt thu be brent?"' (260). This scene wherein Margery speaks from a window to all who will listen is akin to talking from a pulpit. Nevertheless, she tells us that her audience is convinced by what she has to say and that they even cry in disbelief that such a woman as she should be burned. In addition, the most interesting authorisation of her speech comes from God: "Dowtyr, I sent onys Seynt Powyl unto the, for to strengthyn the and comfortyn the, that thu schuldist boldly spekyn in my name fro that day forward. And Seynt Powle seyd unto the that thu haddyst suffyrd mech tribulacyon for cawse of hys wrytyng" (304). Not only does God give her leave to talk boldly in His name, but St. Paul also acknowledges that Margery is suffering because of his writings and that she will receive a reward for these tribulations. Probably aware of the irony, Margery uses the much-quoted St. Paul who forbids women to preach to legitimise her own preaching. She makes sure that in every encounter in which she is labelled as a Lollard, she is able to prove her orthodoxy in the articles of faith. As such, she uses these episodes to counter every accusation whilst simultaneously using them as authorisation for her speeches.

Margery's numerous arrests and confrontations with the public are a common theme throughout her Book. Through all of these encounters, she clearly participates in the political landscape of her time, managing at the same time to prove her orthodoxy as well as to legitimise her voice and impose her will. This is established very early on in the Book in a speech by Christ who tells her the following:

Also, my derworthy dowtyr, thu must forsake that thow locyst best in this world, and that is etyng of flesch. And instede of that flesch, thow schalt etyn my flesch and my blod, that is the very body of Crist in the sacrament of the awter. Thys is my wyl, dowtyr, that thow receyve my body every Sonday, 
and I schal flowe so mych grace in the that alle the world schal mervelyn therof.

Thow schalt ben etyn and knawyn of the pepul of the world as any raton knawyth the stokfysch. Drede the nowt, dowtyr, for thow schalt have the vyctory of al thin enemys. I schal yeve the grace inow to answer every clerke in the love of God. (71-72)

Here, Christ tells her that it is his will that she receive communion every Sunday. On the one hand, this establishes her orthodoxy, in that she states that this "is the very body of Crist in the sacrament of the awter," thus aligning herself clearly against the Lollard's teachings, as discussed above. On the other hand, it also shows Margery's exceptional status as a prophet, because receiving communion this often was rather unusual. Miri Rubin, for instance, states that in late medieval culture "the bread was not simply accessible, and was not frequently to be consumed. Communion was taught as an annual duty, which could be taken perhaps thrice a year on the major feasts of Christmas, Easter and Pentecost, but only after due penance and preparation" (147-48). Thus, receiving communion this often marks Margery's special status as Christ's prophet as well as her purity and readiness to receive it in the first place. Furthermore, in the second part of the statement, Christ prepares her for future encounters in which the public will literarily pull her to pieces. However, it is made clear that she will be able to answer every question that the clerks will ask her and that she will always be victorious over all her enemies by the grace of God.

Shortly after this speech by Christ, the reader encounters one of the first of these confrontations. In Chapter 16, Margery comes to London and rebukes several of Archbishop Arundel's clerks for swearing, something which she criticises throughout her Book. One of the women then tells Margery: "I wold thu wer in Smythfeld, and I wold beryn a fagot to bren the wyth; it is pety that thow levyst" (110). This reference to Smithfield is the first of several which connect Margery to Lollardy, as William Sawtry, a parish priest of the Church of St. Margaret in Lynn was the first Lollard to be burnt at Smithfield in $1401 .^{8}$ Furthermore, a typical feature of Lollards was their objection to the swearing of oaths. In fact, at the trial of William Thorpe, who is often mentioned alongside Sawtry, Thorpe is questioned about five things he said in a 
sermon, all of which belong to the main charges brought against Lollards in general:

That the Sacrament of the Altar after the consecrations was material bread.

And that images should in no wise be worshipped.

And that men should not go on any pilgrimages.

And that priests have no title to tithes.

And that it is not lawful to swear in any wise. (Pollard 121)

Thorpe maintains that "by the authority of the Gospel and of Saint James, and by witness of divers Saints and Doctors I have preached openly, in one place or other, that it is not lawful in any case to swear by any creature" (Pollard 149). Objecting to swearing thus became closely connected to Lollardy during that period.

However, Margery Kempe is then sent for by Arundel himself, from whom she seeks permission to choose her own confessor and to receive communion every Sunday "undyr hys lettyr and hys seel thorw al hys provynce" (110). In this encounter, she is granted everything she asks for, even though "this creatur boldly spak to hym for the correccyon of hys meny" (111), and she, thus, receives his letter and his approval of her way of life. Yet, in other encounters, Margery is openly accused of being a Lollard. The Mayor of Leicester calls her "a fals strumpet, a fals Loller, and a fals deceyver of the pepyl" (229). She is then brought before the Abbot of Leicester who asks her about the "blysful sacrament of the awter" (234) in order to prove that she is a heretic. Margery's answer is orthodox and it shows that she is aware of the dangers that such an answer brings with it. She says:

Serys, I beleve in the sacrament of the awter on this wyse: that what man hath takyn the ordyr of presthode, be he nevyr so vicyows a man in hys levyng, yyf he sey dewly tho wordys ovyr the bred that owr Lord Jhesu Criste seyde whan he mad hys Mawnde among hys disciplys ther he sat at the soper, I beleve that it is hys flesch and hys blood and no material bred. (234-35)

Here, she acknowledges her belief that communion is Christ's flesh and blood and not simply bread - a sentence which is repeated in most of the heresy trials at the time. She also comments on the fact that it has to be an ordained priest who conducts the ritual and that it is of no consequence if he happens to be a vicious man. In raising these additional points, she attempts to distance herself from the Lollards' belief that all virtuous men (and sometimes 
women) can be priests capable of performing the sacraments and from their questioning whether a vicious priest can also perform the sacrament of the altar. $^{9}$ By answering as she does, Margery shows that she is aware of several disagreements between the Church and the Lollards and she addresses them all at once. Though they question her further and seem to be unsure about her, they are obliged to let her go as "sche answeryth ryth wel to us" (235).

From Chapter 46 to Chapter 56, Margery is accused of Lollardy, arrested and imprisoned several times and questioned by bishops, clerks and archbishops. It seems that her attire and her traveling alone initially arouse greatest suspicion. She is asked on several occasions why she wears only white. In York, she is questioned in the following way:

"Woman, what dost thu her in this cuntre?"

"Syr, I come on pilgrimage to offyr her at Seynt William."

Than seyd he ayen: "Hast thu an husbond?"

Sche seyd: "Ya."

"Hast thu any lettyr of recorde?"

"Sir," sche seyd, "myn husbond yaf me leve wyth hys owyn mowthe." (246)

A women traveling without her husband was rather unusual at that time, and her traveling without a letter of permission even more so and this made people very critical of her behaviour. Thus, after this conversation, Margery is again examined in the articles of faith and is, of course, able to answer in full. However, the clergymen of York Minster are not yet satisfied and send her to appear before the Archbishop of York. Furthermore, near Hull, she is arrested by two of the Duke of Bedford's yeomen, because she is "holdyn the grettest Loller in al this cuntre" (258). Apart from being accused of being a heretic, she is also reprimanded for not acting as a woman should: "Damsel, forsake this lyfe that thu hast, and go spynne and carde as other women don, and suffyr not so meche schame and so meche wo" (258-59). The implication is that instead of traveling the country alone, going on pilgrimages and telling people about her way of life, whilst criticising them for theirs, she should rather stay at home, be silent, and spin as women should. From this, we see that her being a woman who travels freely without a male authority seems to be a major cause of concern. isia Moone and Margery Baxters ("Heresy Trials"). 
Margery then is brought before the Archbishop of York again. In this second encounter, she is questioned about her visit to Joan de Beaufort, the sister of Cardinal Beaufort and aunt of the Duke of Bedford. It is said that Margery has counselled Joan's daughter, Elizabeth Greystoke, to forsake her husband. This serious accusation once more ties Margery to Lollardy, given that Lollards such as Hawisia Moone, for instance, held the belief that "oonly consent of love betuxe man and woman, withoute contract of wordis and withoute solennizacion in churche and withoute symbred askyng is sufficient for the sacrament of matrymoyn" (Hudson, English Wycliffite Writings 35). In the eyes of the Lollards, priests and holy sacraments became irrelevant, as men and women could be married by consent alone. This also meant, of course, that a marriage could be dissolved by consent as well, which had even more religious and legal consequences. However, Margery again prevails and manages to prove her innocence. She even asks the Archbishop for his letter and seal: "My Lord, I pray yow late me have yowr lettyr and yowr seyl into recorde that I have excusyd me ageyn myn enmys and nothyng is attyd ageyns me, neithyr herrowr ne heresy, that may ben prevyd upon me" (267). This letter would not only exonerate her from all error and heresy, but it would also give her leave to travel the county without any troubles. The Archbishop "ful goodly grawntyd hir al hir desyr" (267) and Margery is free once again.

Even though Margery is arrested and slandered several times and accused of Lollardy in many of the towns she visits, these episodes are clearly part of her authorisation process. First of all, in all of these encounters, she is able to prove her orthodoxy, as she gives the right answers and furthers her authority by showing the reader that her words are true. As discussed in Chapter 1, slander ties her to Christ and calls attention to her special grace. This special grace, however, is not only connected to Christ, but also very much situated in the earthly realm. Throughout all these episodes, she meets very important people, such as Archbishop Arundel, the Archbishop of York or Joan of Beaufort. The letters and seals, as well as the positive responses to her talk by these people, enhance Margery's authority. They enable her to roam freely around the country and afford her the possibility of choosing her own confessor. She is even allowed to have communion every Sunday and her words in general have more authority. They permit her to teach (or even to preach) all over the country though it occasionally appears that she is walking a thin line of representing exactly that of which she is accused throughout her Book. In addition, all her answers to the clergy prove her awareness of the contemporary political landscape as she uses these episodes to participate in the country's politics. 
Although Julian and Margery do not counsel kings and queens, they certainly participate in the political issues of their day in many different ways. Firstly, a book written by a woman can be seen as a political act in its own right. Furthermore, as politics and religion cannot be separated, both Julian and Margery's own ideas can be seen as subversive and, thus, political. Julian, for instance, contradicts the Church's teachings with her universal salvation theory in which there is no hell and in which all sinners are saved by the grace of God in the end. Furthermore, the writing of religious texts in English can be seen as another political act by these writers. The use of the vernacular and the notion that their texts are for the edification of everyone almost lead to censorship and persecution. Arundel's Constitutions make it clear that even though they are largely aimed against Lollards, they are directed against English religious writings in general. The fear of everybody being able to talk about scripture and theological concepts in general and of the clergy becoming irrelevant is seen in both the Constitutions and the heresy trials. Margery, for instance, holds several views that can be termed heretical, yet she manages to increase her authority by using the political issues with the Lollards for her own ends. Even though she teaches/preaches in public and travels around the country without her husband, the many trials that she has to go through showcase her awareness of the problems of the time and her knowledge in general. She is able to legitimise her talk through various bishops, Joan of Beaufort, as well as the highest authority of all: God. Margery and Julian not only take part in politics, but, for women who should be silent and should not teach in public, they also legitimise their writings as well as their voice exactly through the political landscape of the time that tries to limit them.

\subsection{Katherine Chidley}

As stated in the first chapter, the seventeenth century saw a proliferation of texts by female visionary writers and the decades between 1640 and 1660 contained many revolutionary changes. Andrew Bradstock summarises this aptly:

The combined effect of three very bloody civil wars, the trial and execution of the Archbishop of Canterbury and the king, and the abolition of institutions such as the monarchy, House of Lords, Star chamber, bishops and church courts combined to create a breakdown in censorship which allowed ideas 
hitherto considered heretical and kept underground to surface in print and in word. (xiii)

Many female visionary writers were able to give voice to their hopes, concerns and visions in print at this time. It may well be that the absence of censorship and the revolutionary circumstances made it possible for women to publish to such an extent. Christopher Hill maintains:

During the brief years of extensive liberty of the press in England it may have been easier for eccentrics to get into print than ever before or since. Before 1641 , and after 1660 , there was a strict censorship. In the intervening years of freedom, a printing press was a relatively cheap and portable piece of equipment. (The World Turned Upside Down 17)

Furthermore, Hill also states: "From [...] 1645 to 1653, there was a great overturning, questioning, revaluing, of everything in England. Old institutions, old beliefs, old values came in question. Men moved easily from one critical group to another" (The World Turned Upside Down 14). This is also true of women. Many of them moved from one group to another and participated in the political debates of the time.

Katherine Chidley, a religious controversialist and Leveller active between 1616 and 1653, also used her prophecies for religious and political ends. Her Justification of the Independent Churches and A New-Years-Gift are both responses to the London preacher Thomas Edwards, who is probably most famous for his huge volume Gangraena. In this three-part volume, which consists of approximately 800 pages, Edwards attacks the different sects, such as the Levellers, the Diggers or Ranters, and lists all their errors in the form of a catalogue. He includes letters and pamphlets from people he encounters in order to fight these sects and the toleration of such groups in the Church as well as in the government. On Early English Books Online (EEBO) alone, one is able to find 24 direct responses to Edwards' Gangraena and a further 31 records which mention the work either positively or negatively. Among these responses are also names such as John Goodwin and William Walwyn. Walwyn, for instance, wrote five pamphlets in answer to Gangraena. He not only picks up on Edwards' accusation against him, but also uses similar imagery, such as the use of scripture as authority and disease, in reference to Edwards' title of his text, with a view to highlighting Walwyn's own beliefs and arguments. His belief in love as the foundation of religion and of relationships between human be- 
ings makes a compelling argument against Edwards' often harsh Gangraena, which condemns hundreds of people.

Chidley, however, already has an answer to Edwards' earlier writings such as Antapologia and Reasons Against the Independent Government of Particular Congregations in which he already writes against toleration, Independency and the superiority of the 'true church.' Though Gangraena received many responses, Chidley was the only one to reply to Reasons and among the few who also replied to Antapologia (P.R.S. Baker). This earns her a part in Gangraena:

There is one Katherine Chidly an old Brownist, and her sonne a young Brownish, who not content with spreading their poison in and about London, goe down in to the Country to gather people to them, and among other places have been this Summer at Bury in Suffollke, to set up and gather a Church there [...]. I have great reason to think by the Epistle to the Reader, that Katherine Chidly and her sonne made that Book call'd Lanseters Launce [...]. [A]nd the brasen-faced audacious old woman resembled unto Jael. (Edwards, The Third Part 170)

Here Edwards shows the danger of Katherine Chidley, who not only gathers people around her in London, but also in the country in order to set up different churches. He links the spreading of the independent congregations not only to a gangraene, but also a poison. Interestingly, Edwards insults Chidley as a "brasen-faced audacious old woman" and associates her with Jael. Even though Jael (Judges 4-5) is often represented as a heroic figure, Edwards clearly follows the different tradition "that portrayed her murder of Sisera not as a brave act but as a deceptive, treacherous one" (Conway 51). Rather than seeing her as a heroine, Edwards clearly fears her power.

In Reasons, furthermore, Edwards lists several arguments against independent government and the toleration of different churches. He maintains that "the Great and Present Controversie of these Times is about the Church, and Church Government" (A2). One of the reasons he gives is that these congregations have ministers and officers who are not ordained and he concludes that

[n]o man ever being an ordinary Officer in the Church, without Ordination, let them produce one instance if they can: hence the most learned Divines in reformed Churches tell us, that no man ought to be admitted [. . .] to an ordinary function in the Church unlesse they be lawfully called, and that lawfull calling stands in Ordination as well as Election. (Reasons 3-4) 
Chidley, however, states that the Independent government is Christ's government (Justification 20) and that "well-meaning Christians be the fittest on the earth to make Churches, and to choose their officers; whether they be Taylors, Felt-makers, Button-makers, Tent-makers, Shepherds, or Ploughmen, or what honest Trade soever" (Justification 22-23). Here, she clearly aligns herself with the Leveller belief ${ }^{10}$ that no one has the right to rule over another and that all are created equal. Furthermore, the phrase "Well-meaning Christian" also shows that, if one believes in Christ and acts in accordance with scripture, anyone can be an officer of the church without the need for ordination. This also displays the Leveller sentiment that the existing church government does not act in accordance with scripture and in general does not fulfil the ideals and prerequisites that they should according to these groups. She, thus, declares: "For they that understand but little, doe see and know that that Government is vaine and Popish" (Justification 23).

It is quite fitting that it is a woman who answers Edwards' treatise, as the power of women is part of the discussion as well. One of Edwards' fears is that such toleration will negatively impact men's power over women. This fear that women have power over men can already be seen in his calling Chidley Jael in the quotation above. In addition, he maintains. "O how will this toleration take away [...] that power, authority, which God hath given the husbands, fathers, and masters, over wives, children, servants" (Reasons 26). As seen in the first chapter, Edwards subscribes to the widespread belief that God has given men power over women. According to Edwards, the new toleration would shift these power relations. Without restrictions in church government, anyone would be able to preach, including women. Even though the new congregations were less restrictive and women were able to take part in numerous activities, such as preaching, leading groups and taking part in public discussions, these were nonetheless the exception and women were generally still seen as weak, unfit for politics and definitely not equal to men. Chidley is plainly aware of this fact when she calls herself a "weake Instrument" (Justification 2) and justifies her writing in the following way: "But though these my Answers are not laid downe in a Schollerlik way, but by the plaine truth of holy

10 See Bradstock: "If we can talk about a Leveller philosophy, at its heart was the idea that all people were created equal and that no one had any Cod-given or natural right to govern or rule over another. [...] Levellers shared the disdain which all radicals felt for the clergy of the established church" (31-37). 
Scripture" (Justification 2). In spite of not being a scholar and not being able to write like a man, she has the authority of scripture and the "plaine truth."

Furthermore, her style and the way she answers Edwards point by point illustrate her skills in countering these stereotypes while at the same time appearing to accept them. Her answer to Edwards' fear of men losing power over women is as follows:

To this I answer, O! that you would consider the text in I Cor. $7 .{ }^{11}$ Which plainly declares that the wife may be a believer, \& the husband an unbeleever but if you have considered this text, I pray you tell me, what authority this unbelieving husband hath over the conscience of his believing wife; It is true he hath authority over her bodily and civill respects, but not to be a Lord over her conscience. (Justification 26)

Here, Chidley concedes that a husband has power over his wife's body, but does not have authority over her conscience. Her choice of I Cor. 7 is apt, as it argues that women also have authority over men's bodies and that either a man or a woman should be able to leave their marriage if they do not believe. In Chidley's argument, it is made clear that no one has authority over her conscience, as she is the true believer. Despite using the traditional negative epithets applied to women, such as being weak and not being a scholar, she nonetheless gives him "scholarly" answers and uses scripture to underpin her arguments. She even uses her "weakness" in order to ridicule him. In answer to Edwards' image of gathering up his forces to win this war against toleration (Reasons 20), Chidley answers: "Understanding that you are a mighty Champion, and now mustering up your mighty forces (as you say) [...] But that I (in stead of a better) must needs give you the meeting" (Justification 7). Furthermore, at the end of this justification and her "scholarly" contestation of Edwards' reasons, she states: "But if you overcome me, your conquest will not be great, for I am a poor worme, and unmeete to deale with you" (Justification 80). Chidley, thus, cleverly uses her womanhood to make it impossible for Edwards to refute anything that she says.

11 I Cor. 7: 13-15: "And the woman which hath an husband that believeth not, and if he be pleased to dwell with her, let her not leave him. For the unbelieving husband is sanctified by the wife, and the unbelieving wife is sanctified by the husband: else were your children unclean; but now they are holy. But if the unbelieving depart, let him depart." 
In A New-Years-Gift, she responds to Edwards' next book Antapologia. In it, her disdain for the English Church is evident: "I therfore challenge you now, to prove [by the Scripture] that the Church of England is a true Church, and the Ministry thereof a true Ministry, and that they have a true outward calling, which yet you have not done" (A New-Years-Gift 2). Like Chidley, many Levellers believed that the Church of England was corrupt and only interested in furthering its own cause. Moreover, they believed in freedom of consciousness as well as in a church which was based on scripture and in which members were equal. She, thus, declares: "We pleade but for one intire governement established upon sound principles, unalterable. And not a government which may look with severall faces, in severall times, upon severall occasions, according to mens fancies" (A New-Years-Gift 20). Her argument is, that the clergy and the government should not change daily in order to fulfil their own wishes and desires. This point is also made by Walwyn who makes it clear that the Church of England is not the true church, given that

by their art and sophistry, they lead the poor deluded people in the greatest errors, for maintenance of their own pride, covetousnesse, and luxury [...] advance only themselves and their uncertain Doctrines, for their own ambitious ends only, without any regard to the glory of God, or good of men. (The Vanitie of the Present Churches 10)

As with the discussion of the vernacular in the Middle Ages, Walwyn and Chidley are able to use scripture in order to prove the flaws of the established church. The clergy are no longer the only ones able to read and preach the word of God, as scripture is by now readily available to the public. Being able to read the Bible and to form their own opinion, both Walwyn and Chidley refute the Church as well as the government. ${ }^{12}$

Furthermore, Chidley was not only politically active through her writings, but, according to Ian J. Gentles, also besieged parliament on several occasions when some of the Leveller leaders were imprisoned. In 1653, for instance, when John Lilburne was imprisoned again, she organised a petition with over 6000 female signatures to demand his freedom, even managing to wear down

12 Interestingly, Bradstock also mentions that the Levellers insisted on translating the laws, which were still written either in Norman French or Latin, into the vernacular in order to understand them and, of course, to be able to defend themselves (38). Being able to read the laws or the Bible in their own language would give them the advantage to defend themselves from arbitrary attacks, opinions and rules. 
some of the members of Parliament. Ultimately however, the female signatures did not count before the law (Gentles). Although she may have been a leader in her congregation as well as a business woman and a political figure among the Levellers, there were still limitations to her political power due to her being a woman. Her participation in the pamphlet war at the time as well as her responses to Edwards' two first books is remarkable nonetheless. Despite insisting that she is not a scholar, she clearly offers her response in a learned manner. Furthermore, she not only uses similar imagery and styles as other pamphleteers, but she clearly uses the fact that she is a woman to her advantage.

\subsection{Anna Trapnel}

As part of the Fifth Monarchist movement, Anna Trapnel asserts "the continued significance of the Fifth Monarchist cause at a time when it was under severe pressure. Thus, her writings are a topical response to and intervention in current events; she uses the prophetic mode to express her views on the political situation" (Chedgzoy 248). As mentioned earlier, throughout The Cry of a Stone, Trapnel compares Cromwell to Gideon. ${ }^{13}$ At first, she draws a positive picture of his military prowess, reflecting the optimism of the Fifth Monarchists about the Barebones Parliament or the Parliament of Saints and "the possibility that the aims of the Fifth Monarchist for an end to tithes and to the national church, for radical law reform, even for rule by the godly, would be realized" (Hinds, The Cry of a Stone xxxi). She describes Cromwell in the following way, which is worth quoting in full:

[T]o prove Oliver Cromwell, then Lord-General, was as that Gideon [...] blowing the trumpet of courage and valour [...]; that as sure as the Enemy fell when Cideon and his Army blew their trumpets, so surely should the Scots throughout Scotland be ruinated. Upon this I praised for some hours together, that God had provided a Gideon, and this I saw both by Vision, and Faith, and Prayer and Praises, that God had appointed him for the work of that present day to serve this Nation; and told me that great things should be done. (The Cry of a Stone 6) 
Here, she depicts Cromwell as a great military leader of "courage and valour," with the ability to defeat the Scots and to serve the nation in many "great things." More importantly, she sees Cromwell as appointed by God, and, thus, as evidence of the Lord providing the nation with another Gideon.

Shortly after this, Trapnel has a vision about the dissolution of parliament several days before it happens. Cromwell is still depicted as Gideon while he advocates for the dissolution of a parliament that failed to reform the laws either of the government or the church (The Cry of a Stone 10). ${ }^{14}$ At this point, some of the Fifth Monarchists see Cromwell as another Moses and he is expected to launch the Kingdom of Christ. Shortly after the dissolution, several petitioners ask Cromwell: "First That You, whom we look upon as our Moses, leading Gods people, would be pleased, as alwayes you have been, still to be for the people to God ward, that you may bring the causes unto God, and advance the Scepter of our Lord Jesus" (Severall Proceedings of State Affaires 187, p. 2954). However, this feeling of excitement and hope is very short lived. Soon thereafter Trapnel writes: "the Lord gave me Visions of their breaking up, and of the deadness of Gideons ${ }^{15}$ spirit towards the work of the Lord, shewing me that he was laid aside" (The Cry of a Stone 10). The Fifth Monarchists' feeling of betrayal after Cromwell's taking the title of Lord Protector ${ }^{16}$ becomes increasingly apparent in Trapnel's writing:

I beheld at a little distance a great company of Cattle, some like Bulls, [...] the foremost, his Countenance was perfectly like unto Oliver Cromwels; [...] he run

14 For an account of the dissolution of the Rump as well as an in-depth study on the Fifth Monarchists, see Bernard Capp The Fifth Monarchy Men: "Throughout 1652 the army had expressed its dissatisfaction of the failure of the Rump to carry out reforms, and its refusal to allow fresh elections. The crescendo of Fifth Monarchist and army prayer meetings in 1653 made the issue pressing, and the Rump's alleged plan to replenish its numbers by a series of by-elections, thus postponing indefinitely a dissolution, led Cromwell to feel that action was essential. On 20 April 1653 he took his seat in the House, condemned the Rump's proceedings and, calling in a troop of soldiers, dissolved it by force" (61-62).

15 After taking the title of Lord Protector, Cromwell showed that he was no Gideon. After all, Gideon refused to be king when it was offered to him since only God rules over Israel: "Rule thou over us, both thou, and thy son, and thy son's son also: for thou hast delivered us from the hand of Midian. And Gideon said unto them, I will not rule over you, neither shall my son rule over you: the Lord shall rule over you" (Judges 8:22-23).

16 See also Marcus Nevitt who maintains that "the tenor of the utterances" are "scathing critiques of Cromwell and his regime (7). 
at many precious Saints that stood in the way of him, that looked boldly in his face; he gave them many pushes, scratching them with his horn, [...] and the Lord said, mark that Scripture, Three horns shall arise, a fourth shall come out different from the former, which shall be more Terror to the Saints then the others what went before. (The Cry of a Stone 13-14)

Thus, instead of being the emissary of hope for the Kingdom of Saints, Cromwell is now the bull who prevails against the saints and is the greatest "Terror" for the people. He represents the fourth kingdom, which is the worst one because it destroys the earth before Christ arrives to rule. ${ }^{17}$

Even though Trapnel's disappointment is sometimes palpable and her hymns and songs are quite clearly going against Cromwell, ${ }^{18}$ sometimes the hopes and expectations the Fifth Monarchists had for him still shine through. A reason for this hope is, as Bernard Capp states, that "Cromwell was himself a fellow-traveller until 1653" (The Fifth Monarchy Men 14). Indeed, in a speech from July 1653, for instance, Cromwell addresses the assembly making his millenarian ideas evident:

And why should we be afraid to say or think, that this may be the door to usher in the things that Cod has promised; which have been prophesied of; which He has set the hearts of His people to wait for and expect? We know who they are that shall war with the lamb, against his enemies; they shall be a people called, and chosen and faithful. [...] it is our duty to endeavour this way; not vainly to look at that prophecy in Daniel, 'and the kingdom shall not be delivered to another people.' Truly Cod hath brought this to your hands. (Wilbur Cortez Abbott 64)

Here, Cromwell speaks of the prophecy in Daniel and of how everything happening in that moment can be seen as fulfilling that prophecy. The assembly

Daniel 7:23-27: "Thus he said, The fourth beast shall be the fourth kingdom upon earth, which shall be diverse from all kingdoms, and shall devour the whole earth, and shall tread it down, and break it in pieces. But the judgment shall sit, and they shall take away his dominion, to consume and to destroy it unto the end. And the kingdom and dominion, and the greatness of the kingdom under the whole heaven shall be given to the people of the saints of the most High, whose kingdom is an everlasting kingdom." She, for instance, says at one point: "Write how that Protector shall go, And into graves there lye: Let pens make known what is said, that, They shall expire and die" (The Cry of a Stone 19-20). 
will be witness to the "things that God has promised," and they will become part of the Kingdom of the Saints.

Trapnel thus pleads with God for Cromwell at various points in the beginning of The Cry of a Stone: "Must thy Servant that now is upon the Throne, must he now die and go out like a candel? Oh that thy servant could mourn day and night for him! Oh that he might be recovered out of that vain glorious Counsel" (22). The suggestion seems to be that if only Cromwell could see that he had surrounded himself with the wrong people, he would change course and return to rule with his former fellows of the Fifth Monarchists:

Oh let him now deny, and cast it down, and say: Without these Dignities, and great Titles, I will serve the People and Commonalty; and then wilt thou say to him, thou art my Gideon; Let him consider that thine shall rule over all Nations; and let him say why may not this be the time that it does draw near? (29)

Several days into the trance, however, Trapnel paints a picture that shows Cromwell's failings in the eyes of the Fifth Monarchists: "If he were not (speaking of the Lord Cromwell) backsliden, he would be ashamed of his great pomp and revenue, whiles the poore are ready to starve, and art thou providing great Palaces? Oh this was not Gideon of on old" (50). Clearly, Cromwell has become a king, residing in palaces, while the poor go on wanting. Thus, he has embraced everything the Fifth Monarchists hoped he would change. ${ }^{19}$ Although Trapnel's utterances during her trance in Whitehall also included other topics, Cromwell along with the hopes and disappointments of the Fifth Monarchists are central throughout The Cry of a Stone. Her prophecy is clearly a statement about the political situation at that time.

Furthermore, the prophecies seem to have been taken seriously. The scribe lists several people who came to visit Trapnel during her trance:

[A]mong others that came, were Colonel Sidenham, a member of the Council, Colonel West, Mr. Chittwood, Colonel Bennet, with his wife, Colonel Bingham, Captain Langdon, Members of the late Parliament; Mr. Courtney, Mr.

19 Capp states that "the figures and other sources show that the Fifth Monarchists did attract the very bottom strata of society (excluding paupers), the labourers and servants, that is, apprentices and journeymen" (The Fifth Monarchy Men 85). Cromwell moving into the royal palaces must thus have been one of the great disappointments of the movement. 
Berconhead, and Captain Bawtrey, Mr. Lee, Mr. Feak the Minister, Lady Darcy, and Lady Vermuden. (2)

Several of these, such as Sydenham and Bennett, were members of the Barebone Parliament. The visitors were not all millenarians; Sydenham, for instance, was a supporter of dissolving the Barebone Parliament and thus a supporter of the protectorate. Bennett, however, had millenarian leanings and housed Trapnel during her travels to Cornwall, which can be read about in her Report and Plea. Christopher Feake is probably the most well known Fifth Monarchist and "one of the most hostile and outspoken critics of Cromwell and his government" (Ball). These visits show how much interest there was in millenarian beliefs at the time as well as in Trapnel's status as a prophet.

Her prophecies were more than just a curiosity and were actually seen as a political threat. The pamphleteer and journalist Marchamont Nedham even wrote a letter to Cromwell about Trapnel's trances and prophecies. The note is worth quoting in full:

There is a twofold design about the prophetess Hannah [Trapnel], who played her part lately at Whitehall at the ordinary; one to Print her discourses and hymns, which are desperate against your person, family, children, friends, and the government; the other to send her all over England, to proclaim the viva voce. She is much visited, and does a world of mischief in London, and would do in the country. The vulgar dote on vain prophecies. I saw hers in the hands of a man who was in the room when she uttered them day by day in her trance, as they call it. He promised to lend me them; if he does, I will show you them. They would make 14 or 15 sheets in print. (Calendar of State Papers, February 7,1654 )

Nedham is warning Cromwell about Trapnel, fearing that she is part of an evil plan that might have an effect on the Lord Protector and his family as well as on the government. He also stresses the fact that Trapnel not only dares to print her prophecies, she also travels all over England to give voice to them. The fact that she is visited by many people shows further the influence and possible threat of the public spectacle of her trances. Thus, Trapnel's prophecies have an impact not only on people who read them or hear her uttering them, they also have a political dimension.

In Trapnel's Report and Plea, an account of her travels to Cornwall, she is brought before a judge where she faces similar questions to the ones Margery had been asked on several occasions. In keeping with Nedham's concern, and 
the concern of several people in Margery's case, the focus of the judge's questioning is on the fact that Trapnel is a single woman who travels alone. Justice Lobb questions her:

How it came to pass, that I came into that Country.

I answered I came as others did that were minded to go into the Country.

Lobb. But why did you come into this Country?

A.T. Why might not I come here, as well as into another Country?

Lobb. But you have no lands, nor livings, nor acquaintance to come to in this Country.

A. T. What though? I had not I am a single person, and why may I not be with my friends anywhere?

Lobb. I understand you are not married.

A. T. Then having no hindrance, why may not I go where I please, if the Lord so will?

A woman traveling alone, without a husband, raises concern and is likely to cause "a world of mischief," as Nedham warned. It means that she is traveling without the supervision of a man. However, just like Margery, Trapnel is able to legitimise her travels through God, claiming that "[t]he Lord gave [her] leave to come" (26.1).

It is not just Trapnel's independence that worries the authorities. There is also the age-old fear of the seductiveness of a woman's voice: "Justice Lobb told me, I made a disturbance in the town: I asked, Wherein? he said, By drawing so many people after me" (Report and Plea 28.1). It seems that the judge is concerned that Trapnel is leading people astray simply by talking to them, even if what she says is actually true and in line with the Church's teaching. Indeed, it is made clear again and again that she is telling the truth, and is using scripture as well as voicing what God is telling her. For example, during the examination in front of the judge, she is perfectly able to answer all the questions. From the start, however, she makes sure that the reader knows that the words leaving her mouth are not her own: "Are you guilty, or not? I had no word to say at the present; but the Lord said to me; Say Not guilty" (Report and Plea 24). Furthermore, as Margery did with the clerks who judged her, Trapnel quotes scripture and turns the table on the judge:

A.T. I will take you up [on] your word, in which you said, I was not to judge: you said well; for so saith the Scripture, Who art thou that judgest anothers mans servant? To his own master he standeth or falleth; yea, he shall be holden up, 
for Cod is able to make him stand: but you have judged me, and never heard me speak [...] I said, I will leave one word with you, and that is this: A time will come when you and I shall appear before the great Judge of the tribunal seat of the most High, and then I think you will hardly be able to give an account for this days work before the Lord, at that day of true judgement. (Report and Plea 27.1-28.1)

Here, Trapnel boldly speaks out against the accusations of the judge and maintains that the "day of true judgement," which is, of course, far more important than the judgement happening there in Cornwall, will favour her.

Before that, however, she, like Margery before her, will have to face the judgement of those around her, including answering accusations about being a witch:

Some at Dartmouth reported that I had bewitched the winds, that the ships could not go to sea, and they cursed me there, but the Lord blessed me the more; many reproaches he helpt me to bear, and though we were beating on the waves against the wind, yet I was not sick. (Report and Plea 35$)^{20}$

She is accused of having power over the winds and of, therefore, being responsible for interfering with the lives of ordinary people who are dependent on the weather for their business. However, as already mentioned in the first chapter, this episode is further proof of the connection that Trapnel has with Christ, as she humbly accepts any slandering in his name. Moreover, Christ not only helps her to bear the reproaches, she also does not get sick in the storm, which can be seen as another sign that she is blessed by Christ. As in Dartmouth, her appearance before the judge in Cornwall is related to accusations of her being a witch: "but the report was, That I would discover my self to be a witch when I came before the Justices, by having never a word to answer for my self; for it used to be so among the witches, they could not speak before the Magistrates" (Report and Plea 25). In this case being a witch means that one is not able to answer questions in front of a judge. However, Trapnel, as stated above, is able to counter the judge's questions with the help of God and thus proves that she cannot be a witch. ${ }^{21}$ This notion is further

20 Margery faces similar accusations: "for it was telde hir yyf thei haddyn any tempest, thei woldyn castyn hyr in the se, for thei seyd it was for hir; and thei seyde the schip was the wers for sche was therin [...] And so sche toke hir schip in the name of Jhesu and seylyd forth wyth hir felaschip, whom Cod sent fayr wynde and wedyr" (226-27). the dialogue is as follows: "Ther wer men of lawe seyd unto hir: 'We han gon to scole 
confirmed by the people who she encounters after the trial: "And as I went in the croud, many strangers were very loving and careful to help me out of the croud: and the rude multitude said, Sure this woman is no witch, for she speaks many good words, which the witches could not" (Report and Plea 28.1). On the one hand, being able to "speak good words" and quoting scripture is proof of Christ's blessing. On the other, it is a slippery slope that causes their problems in the first place. Even though these women have to face all these accusations, they are still able to justify their preaching, their writing, and their individuality quite cleverly.

All female visionary writers we have seen in this chapter are clearly political in their writings, able to voice their concerns and assert themselves through participating in the political discussions of their time. Even though Julian and Margery are often seen as "local" prophets and less political than other visionary writers, they do take part in the political landscape of the day. Julian's universal salvation, for instance, decidedly goes against the teaching of the Church. Firstly, her revelations are intended for everyone. They are a message from God without an intermediary priest. Secondly, her parable about God and the servant is at the heart of her universal salvation theory. By interchanging Adam with Christ and Christ with Adam, Julian develops a theodicy in which everyone is a sinner but everyone, without exception, will be saved in the end. Furthermore, in Julian's revelations, there is no hell and she vindicates not only Eve but also the body in general by clearly stating that Christ is part of the flesh and our sensuality. Even though Julian states time and time again that she believes in the teachings of the Church, her revelations break with these teachings in very important ways and are, thus, unquestionably political.

Both Julian and Margery are part of the political discussion about language at the time. Not only do they have to negotiate the century old concept of the via negativa, which postulates that fallible human language cannot be used to talk about an infallible God but they are also political in using the

many yerys and syet arn we not sufficient to answeryn as thu dost. Of whom hast thu this cunnyng?' And sche seyd: 'Of the Holy Cost.' Than askyd thei: 'Hast thu the Holy Cost?' 'Ya, serys,' seyd sche, 'ther may no man sey a good worde wythowtyn the yyft of the Holy Cost, ofr owr Lord Jhesu Crist seyd to hys disciplys, 'Stody not what ye schal sey, for it schal not be yowr spiryt that schal spekyn in yow, but it schal be the spiryt of the Holy Cost"' (269). 
vernacular to write about their revelations. In 1409, Thomas Arundel, Archbishop of Canterbury, published his Constitutions in which he countered the Lollards' aim to bring religion to the people and urged to restrict religious discussions to Latin or Greek. The fear that the clergy would become obsolete, if everyone were able to read and teach the Bible, is clearly visible in Arundel's Constitutions. Within this context, Margery and Julian's use of the vernacular to talk about theology, scripture, and contemplation and their ability to reach a wider audience through that language is politically subversive and potentially dangerous.

Margery, furthermore, displays several beliefs and attitudes that could be called heretical. She has to defend herself on several occasions throughout her Book and shows that she is acutely aware of her political surroundings. These encounters with the public as well as with several bishops, archbishops, and the clergy in general are a common thread running through the Book that give her the possibility to establish her authority as a prophet each time. She is able to show that she knows scripture and that what she is saying (sometimes even preaching) is aligned with the Church's teachings. She walks the thin line of being too forward with several high members of the Church, of preaching rather then talking with the public, and of spreading her revelations during her travels throughout the country. She even includes a dialogue with God who allows her to speak boldly in his name and sends her St. Paul who acknowledges that she has had to suffer because of his writings. In the end, Margery is allowed to travel freely around the country, to choose her own confessor and to receive communion every Sunday. She is able to assert herself in front of very important people as well as in front of the reader making the impression of a clever negotiator and a true prophet with a close connection to God and Christ.

The female visionary writers of the seventeenth century, such as Katherine Chidley and Anna Trapnel, also used their writings for religious and political ends. Chidley, for instance, responds to Edwards' Antapologia and Reasons, and not only displays an awareness of the concerns of her time, but also demonstrates a sophisticated writing style that is thought to be impossible for a female writer. She is politically active when petitioning for the freedom of John Lilburne or by incorporating Leveller beliefs and concerns in her writing. In her responses to Edwards, she uses scripture to refute Edwards and to show that no one has the right to rule over another because everyone is created equal. Furthermore, she negotiates being a woman who possesses a 
conscience of her own and individual autonomy, and she actively participates in political discussions.

Likewise, Trapnel furthers the cause of the Fifth Monarchists in The Cry of a Stone, where she recounts the revelations that she received in Whitehall over a period of twelve days. In believing that the reign of Christ on earth is imminent, she inserts her beliefs directly into the political events of her time. Cromwell is likened to Gideon who saves them and leads them into the government of the Saints. However, by failing to reform the laws and the church government and by accepting, in the end, the title of Lord Protector, Cromwell loses his status as Gideon, inviting Trapnel's evident disappointment. Her political influence is further demonstrated by the many visits she received from important people, such as Feake and numerous members of parliament, during her trances. This compels Nedham to write to Cromwell to warn him of the dangers posed by Trapnel to him, his family, and the government. Her travels across the country are also perceived as a threat. As with Margery, she is able to lure people away and is called a witch on several occasions during her travels. Trapnel, however, is able to consistently justify her voice and her writings by standing up firm against the judges and by showing to the people the special grace she has received from God. Despite the fact that women were forbidden from participating in politics, these women were able to have a political voice in their writings. The main focus of the next chapter, thus, will be to show a continuation of the struggle for female authorship and autonomy in these visionary writings by making writing and authorship themes in their own right. 